DOI: 10.46340/eujem.2020.6.5.2

\author{
Yevhen Ionin, ScD in Economics \\ ORCID ID: https://orcid.org/0000-0002-2903-3143 \\ Vasyl' Stus Donetsk National University, Ukraine \\ Liliia Tarasenko \\ ORCID ID: https://orcid.org/0000-0001-8224-5113 \\ Vasyl' Stus Donetsk National University, Ukraine

\section{INTEGRATION OF THE GAS MARKET OF UKRAINE INTO THE EU GAS MARKET: ISSUES OF MANAGING THE WORKING CAPITAL OF JOINT STOCK COMPANIES}

The gas industry of Ukraine is a significant component of the fuel and energy complex of the country. Being a party to the Treaty establishing the Energy Community, and also in the framework of the signed association agreement with the EU, the natural gas market is undergoing significant transformations. Such transformations are directly related to each of the market participants and primarily gas distribution companies, which provide gas transportation of the gas supply company to consumers with the maintenance of this process.

The effectiveness of the Ukrainian gas market integration into the EU gas market depends on a number of organizational and economic issues. In addition, the political and social components should be taken into account. Resolving this issue is impossible without a clear vision of the economic component, which is a kind of basis for ensuring the integration of the domestic gas market.

Joint stock companies - gas distribution companies - have to operate in accordance with the goingconcern concept, efficiently, providing consumers with gas. Activity on a base of going concern concept is impossible without meeting with certain requirements, namely the availability of working capital and profitable work. The first one, on the whole, guarantees potential solvency, the second one - is evidence of efficient work. In other words, one of the most important indicators of the management system, which is oriented on the process of providing consumers with gas in the euro integration conditions, is a certain increase in the absolute rate of working capital.

In addition, the necessity of the introduction of the relative indicator system of working capital in comparison with sales, assets, equity, cash flows, and others into the current management practice is justified in the investigation. This gives an opportunity to use a number of indicators: working capital turnover, working capital per currency unit of sales on accrual and cash basis.

The system of absolute and relative indicators of working capital is considered as a basic component of providing key performance indicators (KPIs). Monitoring of these indicators for compliance with a certain level is the key to the success of the integration process of the Ukrainian gas market into the EU market.

Keywords: integration, joint-stock companies, gas distribution companies, working capital, working capital turnover, key performance indicators.

Problem setting and its relevance. Gas distribution system operators execute vital function on the natural gas market. Its organizational and legal form is joint stock companies. Joint stock companies operate on the basis of self-financing and self-sufficiency, which is a background of the desire of such enterprises' owners to achieve effective activity.

Unprofitable nature of such type of activity actualizes the search for a system of indicators, management of which directs to achieve efficiency of activity at constant maintenance of process of gas supply. The fact, that such enterprises functioning in socially significant industry, which provides safe and high-quality provision of gas consumers with service of its distribution, adds value to the research issue. 
Fulfillment of functional purpose by gas distribution companies is impossible without the availability of working capital, which is the guarantor of potential solvency on the one hand, ie provide activity based on the going concern principle, on the other hand - growth of its positive size is a consequence of profitable work. Thus, this indicator makes it possible to combine two important requirements: providing consumers with gas constantly and efficiency of activity.

In the system of these enterprises' management next to the absolute value of working capital the system of its relative indicators in comparison with sales, equity, profit, net cash flow has to be involved. Therefore, it is vital not only to develop such indicators but also establishing its recommended values, the possible range of its fluctuations.

Analysis of recent research and publications on the topic of research. Issues on the working capital role and approaches to its management are devoted to the research of the following scientists: Blank I, Ionin Y, Kvasnitska R, Morozovkiy Y, Solyanyk L. At the same time, issues related to the turnover of working capital of joint stock companies engaged in gas distribution, which are carrying out activities in the industry, which is characterized by the national importance, affects the state of public welfare are taken on special research needs.

The purpose of the article is to identify the changes, which are taking place on the gas market and its impact on the performance of joint-stock companies in the field of gas distribution. Theoretical justification of working capital role and financial ratios on its base as fundamental in the system of key performance indicators, which are focused on the implementation of Ukraine's gas market integration into the EU market.

Presentation of the main material. Reforms on the natural gas market of Ukraine, initiated in 2014, are focused on the changing the energy panorama of the country. The natural gas market, in accordance with established norms, functions on the basis of free good faith competition, with the exception of the activity of subjects of natural monopolies, and on the following principles ${ }^{1}$ :

1) safeguarding of the high level of protection of rights and interests of consumers of natural gas, including safeguarding of the first-hand interest of the security of supply of natural gas, including through diversification of sources of natural gas supply;

2) free trade in natural gas and equal treatment of subjects of the natural gas market regardless of the state under the laws of which they are established;

3) free choice of supplier of natural gas;

4) equality in the right to carry out import and export of natural gas into/from Ukraine.

From the beginning of the gas market reformation organizational approaches in its functioning are fixed by legislative acts, which are developing on the base of already established rules, which operate in the European Union. Among key norms, implementation of which has been achieved, are taking place now or will be taking place, are following:

1. Prohibition of simultaneous distribution and supply of natural gas by one business entity. Legal separation (unbundling), which is a requirement of EU Directive, has been fulfilled, activity of gas supply has been separated from gas distribution activity in 2015. It should be mentioned, that in most cases, established gas supply companies are limited liability companies, which are subsidiaries of joint-stock companies - gas distribution companies. Aforementioned legal entities created a group of enterprises, where the first one - carries out activities of distribution of natural gas via a gas distribution system and performs operational and technological management functions in relation to it, the second - carries out natural gas supply. The implementation of such a measure as separation of functions is in line with the principle of free competition, which is the basis of the functioning of the natural gas market of Ukraine. This is also a step towards consumer protection in the free choice of supplier.

2. Creation of the fully-fledged market, which provides consumers with a free choice of gas supplier. This requirement has been met partially. Only legal entities have a free choice of supplier. Accordingly, this requirement does not fully comply with the principles of Law of Ukraine «On the natural gas market», namely - principle of free choice of supplier of natural gas.

3. Establishing on the natural gas market prices, in particular tariffs for distribution, which are nondiscriminatory, transparent, economically justified (taking into account the due level of return). Tariffs shall encourage effective trade in natural gas, development of competition, shall create economic stimuli for investments.

${ }^{1}$ Закон про ринок природного газу, 2015 (Верховна Рада України). Офіџійний вісник Украӥни, 37, 67. 
4. Introduction of metering and settlements of gas volume in energy units on the natural gas market. Practice of using energy units for gas metering and settlements for consumed volume of natural gas is standard in Europe. Ukraine is currently making its first attempts at transition to such method. This approach is justified from the point of view observance of such principle as protection of rights and interests of consumers of natural gas. Due to the fact, that there are known cases, when consumers complained about the quality of gas, fee for consumed natural gas based on the level of its calorific value, and not for the burned cubic meters, is within framework of consumer's interest.

To achieve goals, which was set in the direction of forming a free and competitive market environment, a number of reform measures are being implemented. These measures apply to all natural gas market participants, where distribution gas companies, main function of which is to deliver gas to the final consumer play an important role.

Developing the measures, connected to bringing the gas market to European standards and its implementation has a certain level of influence on the activities of economic entities operating in this field. Implementation of each new legal norm in the gas industry has certain level of influence on the interests of market participants, which, in particular, are joint-stock companies for gas distribution and consumers.

Joint-stock companies - gas distribution enterprises - focused on achieving economic efficiency. To measure degree of efficiency and further management of activity an analysis of various indicators is required. Among fundamental indicators of determination the level of safeguarding the efficiency of gas distribution enterprises' functioning, which are characterize enterprises' solvency and efficiency of resources' financing structure are working capital and numerous financial ratios based on it. Among these ratios, working capital turnover should be highlighted. The first indicator is a characteristic of the safeguarding of enterprise' functioning, the second - signals about the level of efficiency.

Changes, as external factors, which are occurring in connection with the implementation of European legislation should be estimated from the point of view its potential impact on working capital. In addition, the latest changes, namely the transition to settlements and balancing in energy units, should be taken into account. These changes will allow':

1) to introduce a differentiated gas prices depending on its quality as a commodity;

2) to bring the gas parameters in the domestic market of natural gas to its parameters at the customs border of Ukraine with the European Union;

3) to increase energy efficiency through consumers participation in the management of their own energy consumption including through analysis/comparison of gas volumes in units of energy with alternative energy sources (electricity, heat) (Table 1).

The level of external factors' impact, namely legal changes, is largely depends on a development scenario of particular measures, which are still remaining at the discussion stage and aren't finally solved. At the same time, potential consequences and the options for its managing are need to be understood.

For efficient management, executive staff need to have information, the interpretation of which represents the state of affairs of the enterprise. Such information could be presented as scorecard, which is relevant. It means this scorecard corresponds with current challenges of company.

For joint-stock companies, which are carrying out activity of gas distribution, inventories, cash, trade receivables are vital resources, because listed assets embodies the receipt of economic benefits. On the other hand, the source of assets financing is equity and liabilities. Excess of current assets over current liabilities is one of the condition, that company operate on a going concern basis, which is reflected in the working capital indicator.

Idea of using the working capital indicator to diagnose potential solvency is very obvious and based on a potential cash flows. Current assets are potential positive cash flow during the one year, whereas current liabilities are potential cash outflow. The norm of the business is presence of positive working capital. This is a confirmation of potential solvency within one year ${ }^{2}$.

\footnotetext{
${ }^{1}$ Проект Закону Украӥни про внесення змін до деяких законодавчих актів Украӥни щзодо запровадження на ринку природного газу обліку та розрахунків за обсягом газу в одинииях енергії, 2019

(Верховна Рада України). Офіиійний сайт Верховної Ради Украӥни

<http://w1.c1.rada.gov.ua/pls/zweb2/webproc4_1?pf3511=67572> (2020. September, 15).

${ }^{2}$ Іонін, Є. Є. (2019). Діагностика відповідності платоспроможності базовим концепціям бухгалтерського обліку Фінанси, облік, банки, 1 (24), 129-137
} 
Table 1

\section{Assessment of the changes on the gas market: impact on working capital of joint-stock companies}

\begin{tabular}{|c|c|}
\hline $\begin{array}{l}\text { Type of change, } \\
\text { implementation date }\end{array}$ & Impact on working capital of joint-stock companies \\
\hline $\begin{array}{l}\text { Separation (unbundling) } \\
\text { economic activity of natural gas } \\
\text { supply from distribution } \\
1^{\text {st }} \text { of July, } 2015\end{array}$ & $\begin{array}{l}\text { There is no significant impact on gas distribution company as a separate legal } \\
\text { entity. Due to the fact, that the company is natural monopolist all household } \\
\text { customers and all industrial enterprises are remain its client. } \\
\text { Due to the fact, that function separation directed towards development the } \\
\text { competition in the gas supply segment, natural gas supplier fall within the scope } \\
\text { which is manifested by the appearance and gradual increase of competitors on the } \\
\text { market. In case the client churn, level of enterprises' current assets is going down } \\
\text { coupled with decreasing of current liabilities connected with the gas purchase. } \\
\text { As a whole, reduction in profits lead to reduction in working capital }\end{array}$ \\
\hline $\begin{array}{l}\text { Allocation the bill of natural gas } \\
\text { distribution service } \\
1^{\text {st }} \text { of January, } 2020\end{array}$ & $\begin{array}{l}\text { In existence of separate bill for gas distribution, the companies get funds } \\
\text { for the services provided by a direct way. This provides faster receipt } \\
\text { of the most liquid resources. At the same time, this effect will be minimized due } \\
\text { to reduced payment discipline at the first stage. This will be the reason } \\
\text { of increase in trade receivables }\end{array}$ \\
\hline $\begin{array}{l}\text { Introduction of metering and } \\
\text { settlements for gas in energy } \\
\text { units on the natural gas market } \\
16^{\text {th }} \text { of June, } 2020 \text { (draft law) }\end{array}$ & $\begin{array}{l}\text { These changes connected with the technical re-equipping, primarily, gas } \\
\text { metering devices. Financing of the metering equipment replacement can be } \\
\text { implemented in such alternative ways: } \\
\text { 1. Including the expenses of metering equipment replacement into } \\
\text { the distribution tariff. This approach is the most justified. However, the program } \\
\text { of metering devices replacement will be stretched over time on the one hand, } \\
\text { and will be an additional burden for consumers - on the other hand. As a result, } \\
\text { there will be increase of trade receivables as a component of working capital. } \\
\text { It is possible that such receivable in some cases could be determined } \\
\text { as uncollectable debts and then written off as the cost. } \\
\text { 2. In case of absence of expense coverage, liabilities of gas distribution } \\
\text { companies will be the source of funding. Gas distribution companies will be } \\
\text { forced to accumulate accounts payable. There is an increase of current liabilities } \\
\text { as a component of working capital. However, this scenario is unlikely, } \\
\text { for the following reasons: there is a bankruptcy risk for gas distribution } \\
\text { companies because of the debt accumulation, creditors will not agree to long- } \\
\text { term deferral of payment. }\end{array}$ \\
\hline $\begin{array}{l}\text { Changes of tariffs for natural } \\
\text { gas distribution services, } \\
1^{\text {st }} \text { of January } 2020,1^{\text {st }} \text { of July } \\
2020\end{array}$ & $\begin{array}{l}\text { Tariff increase will have a simultaneous impact on the working components: } \\
\text { 1) increase in asset part (by the increase of income, which provides funds flow); } \\
\text { 2) decrease of liabilities, the covering source of which is assets outflow, which } \\
\text { was gained as a result of distribution services provision (cash). }\end{array}$ \\
\hline
\end{tabular}

Relative indicators (financial indicators) can enhance usefulness of information on working capital. For a broader and more specific interpretation of the amount of working capital, it is necessary to compare the level of this indicator with others. For example, it is advisable to compare company's income, profit, net cash flow with working capital and vice versa. Working capital and financial ratios, calculated on its base, create a scorecard, which allows interpreting data about the activity of joint-stock company for the efficiency assessment (table 2).

Indicators of working capital turnover assist in the process of gaining an understanding of the company's effectiveness, namely how the policy of company on working capital using is efficient for generation of sales, profit or cash flow.

It should be highlighted, that individual result of working capital turnover ratio can't provide information with a high value, due to the fact, that high turnover isn't an evidence of absolute positive position, and low - negative. This thesis is true for most financial ratios. On this basis, analytical information is needed in dynamics and in comparison with the recommended values. Unfortunately, such information is absent in Ukraine. The dynamics of such indicators will subsequently make it possible to determine industry norms (recommended values) for each of them. 
Table 2

Relative indicators in assessing the efficiency of working capital

\begin{tabular}{|c|c|c|}
\hline Name of indicator & Formula & Interpretation \\
\hline Working Capital Turnover (WCT) & $\begin{array}{l}\quad \text { WCT }=\frac{S}{W C} \text {, where } \\
\mathrm{S}-\text { sales (net income); } \\
\mathrm{WC}-\text { working capital }\end{array}$ & $\begin{array}{l}\text { - number of working capital } \\
\text { turnovers; } \\
-\quad \text { sales volume per } 1 \\
\text { currency unit of working capital }\end{array}$ \\
\hline $\begin{array}{l}\text { Return on Working capital based on } \\
\text { accrual method }\left(\mathrm{RWC}_{\mathrm{p}}\right)\end{array}$ & $\begin{array}{l}\quad R W C_{P}=\frac{P(L)}{W C} \text {, where } \\
\mathrm{P}-\text { profit; } \\
\mathrm{L}-\text { loss. }\end{array}$ & $\begin{array}{l}\text { volume of profit (loss) } 1 \text { currency } \\
\text { unit of working capital }\end{array}$ \\
\hline $\begin{array}{l}\text { Return on Working capital based on } \\
\text { cash method }\left(\mathrm{RWC}_{\mathrm{CF}}\right)\end{array}$ & $\begin{array}{l}\quad R W C_{C F}=\frac{\mathrm{CF}}{W C} \text {, where } \\
\mathrm{CF}-\text { net cash flow }\end{array}$ & $\begin{array}{l}\text { Volume of net cash flow per } 1 \\
\text { currency unit of working capital }\end{array}$ \\
\hline $\begin{array}{l}\text { Ratio for sales by working capital } \\
\text { (security of income (sales) by working } \\
\text { capital) }\left(\mathrm{RS}_{\mathrm{WC}}\right)\end{array}$ & $R S_{W C}=\frac{W C}{S}$ & $\begin{array}{l}\text { - volume of working capital } \\
\text { per } 1 \text { currency unit of sales; } \\
\text { - } \quad \text { own working capital } \\
\text { per } 1 \text { currency unit of sales }\end{array}$ \\
\hline
\end{tabular}

Resource: built by authors

Thus, it would be advisable to select profitable joint-stock companies engaged in gas distribution to derive recommended values to guide the decisions on working capital management. However, unfortunately, the operators of the gas distribution system in Ukraine remain unprofitable for several recent years, have a negative value of working capital and, accordingly, the working capital turnover (Table 3).

Table 3

\section{Main financial indicators of joint stock companies - operators of gas distribution system}

\begin{tabular}{|c|c|c|c|}
\hline \multirow{2}{*}{ Date } & \multicolumn{3}{|c|}{ Distribution system operators } \\
\hline & Vinnytsiagas & Volyngas & Zhytomyrgas \\
\hline \multicolumn{4}{|c|}{ Net loss, thousand UAH } \\
\hline For the year ended December 31, 2017 & $(48005)$ & $(22360)$ & $(55449)$ \\
\hline For the year ended December 31, 2018 & $(115218)$ & (69 317) & $(146931)$ \\
\hline For the year ended December 31, 2019 & $(317725)$ & $(177374)$ & $(400110)$ \\
\hline \multicolumn{4}{|c|}{ Net income(sales), thousand UAH } \\
\hline For the year ended December 31, 2017 & 621963 & 390073 & 408840 \\
\hline For the year ended December 31, 2018 & 585663 & 352712 & 410980 \\
\hline For the year ended December 31, 2019 & 531868 & 314132 & 344749 \\
\hline \multicolumn{4}{|c|}{ Working capital, thousand UAH } \\
\hline As at $31^{\text {st }}$ December 2017 & $(347784)$ & (195 392) & $(122743)$ \\
\hline As at $31^{\text {st }}$ December 2018 & $(498$ 109) & (369 486) & $(266643)$ \\
\hline As at $31^{\text {st }}$ December 2019 & $(850402)$ & $(533712)$ & $(679628)$ \\
\hline \multicolumn{4}{|c|}{ Working capital turnover } \\
\hline As at $31^{\text {st }}$ December 2017 & $(178,84)$ & $(199,64)$ & $(333,09)$ \\
\hline As at $31^{\text {st }}$ December 2018 & $(117,58)$ & $(95,46)$ & $(154,13)$ \\
\hline As at $31^{\text {st }}$ December 2019 & $(62,54)$ & $(58,86)$ & $(50,73)$ \\
\hline
\end{tabular}

Resource: company financial statements, author's calculation 
For the last 3 years the distribution system operators are characterized by the presence of net loss, which has a negative tendency to a significant increase: Vinnytsiagas - 6.6 times, Volyngas -7.9 times, Zhytomyrgas - 7.2 times. At the same time - the volume of activity decreases: Vinnytsiagas by $15.5 \%$, Volyngaz by $19.5 \%$, Zhitomyrgaz by $15.7 \%$.

The amount of current liabilities of gas distribution companies exceeds the volume of current assets, accordingly, the working capital is presented as a negative value, which is a result of unprofitable activity, evidence of inefficient use of assets and capital in the process of income generation. The duration of the absence of gas distribution tariff revision should be taken into account. Taking into account the presence of a negative trend of a significant increase in the net loss, it is reasonable to introduce a limit value of expenses per $1 \mathrm{hrn}$. of sold products into the management accounting system. The formation of this indicator should take into account a number of factors: actual costs, inflation rate, price index, minimum wage growth, etc.

Thus, the presence of systematic losses, the negative value of working capital make it possible to draw a general conclusion that gas distribution companies are not economically ready for long-term work in the integrated gas market of the EU.

Due to the lack of enterprises in this segment that could serve as a benchmark for establishing and developing recommended values, it is necessary to search for and use another basis. Thus, similar operators of gas distribution network are electricity distribution network operators, whose activity, in contrast to gas distribution enterprises, is profitable (Table 4).

Table 4

Main financial indicators of electricity distribution network operator

\begin{tabular}{|l|c|c|c|c|c|c|}
\hline \multirow{2}{*}{\multicolumn{1}{|c}{ Indicators }} & \multicolumn{4}{c|}{ Electricity distribution network operator } \\
\cline { 2 - 7 } & \multicolumn{2}{|c|}{$\begin{array}{c}\text { Vinnytsia } \\
\text { oblenergo }\end{array}$} & \multicolumn{2}{c|}{$\begin{array}{c}\text { Volyn } \\
\text { oblenergo }\end{array}$} & \multicolumn{3}{c|}{$\begin{array}{c}\text { Prykarpattia } \\
\text { oblenergo }\end{array}$} \\
\cline { 2 - 7 } & 2017 & 2018 & 2017 & 2018 & 2017 & 2018 \\
\hline $\begin{array}{l}\text { Net income from product } \\
\text { sales, thousand UAH (S) }\end{array}$ & 3410750 & 3814888 & 1933566 & 2250689 & 2631352 & 3279700 \\
\hline $\begin{array}{l}\text { Net financial result, thousand } \\
\text { UAH (P (L)) }\end{array}$ & 294139 & 81403 & 13878 & 13984 & 140209 & 249079 \\
\hline $\begin{array}{l}\text { Working capital, thousand } \\
\text { UAH (WC) }\end{array}$ & 146142 & 5984 & $(62415)$ & $(32384)$ & $(78163)$ & $(37628)$ \\
\hline $\begin{array}{l}\text { Working capital turnover } \\
\text { (WCT) }\end{array}$ & 23,3 & 637,5 & $(31)$ & $(69,5)$ & $(33,7)$ & $(87,2)$ \\
\hline
\end{tabular}

Resource: company financial statements, author's calculation

Despite the fact that the net financial result of each company is profit, working capital is not always positive due to the structure of assets and liabilities, the rate of change in current assets and short-term liabilities.

At the same time, comparing the data for 2018 and 2017, it should be noted, that with the increase in profit of joint stock companies, the working capital indicator improves and vice versa, as the net financial result decreases, the working capital level decreases.

The presence of negative values of working capital for gas distribution network operators and electricity distribution operators is an indicator that signals the risk of loss of financial stability, ensuring continuous operation, as in this case a part of long-term assets is financed by short-term liabilities. And that's grounds for possible bankruptcy.

Issues about working capital management are connected with the availability of variable strategies for choosing the proportion of sources of financing of enterprise assets.

Kvasnitska R. and Morozovskiy Y. in their research investigated the following strategies of assets financing in detail: ideal, aggressive, conservative, moderate (compromise). Each strategy provides options for correlation of borrowed sources in asset financing to maximize performance. The authors identified an additional subtype of aggressive strategy, in which non-current assets are financed by equity and short-term borrowed capital, and all current assets are financed by short-term borrowed ${ }^{1}$.

\footnotetext{
${ }^{1}$ Квасницька, Р. С., Морозовський, Я. Е. (2019) Аналіз підходів (стратегій) фінансування активів підприємства Східна Свропа: економіка, бізнес та управління, 1 (18), 241-249.
} 
This approach is currently observed in the activities of joint stock companies engaged in gas distribution. The working capital of these companies is negative, which causes unstable financial position of the enterprise, is a risk of losing solvency by enterprise.

Balanced management of sources of company's assets financing has a significant impact on sustainability and performance of companies. On this basis, working capital and working capital turnover are needed to be under a permanent control by management, because its value directly affects the achievement of company's strategy goals.

Joint-stock companies engaged in gas distribution are functioning in socially significant sphere, which implies the need for their stable, effective, continuous functioning, where, accordingly, the factor of availability of current assets for the realization of daily goals of the enterprise plays a vital role. At the current stage of economic development, the issues of introduction of key performance indicators (KPIs) are characterized by intensification. KPIs - indicators, which are critical to the design and implementation of measures aimed at increasing efficiency ${ }^{1}$. Working capital turnover - relative indicator, which could be chosen as a KPI for joint-stock companies, engages in activity of gas distribution.

In the work by David Parmenter, a significant emphasis has been placed on the fact that the achievement of a particular indicator depends on the work of each of the employees, and thus should be understandable to each of them. Such indicators should be developed for all departments of the enterprise, all team members should be aware that their contributions shape the results of the entire enterprise ${ }^{2}$.

It should be noted that when choosing the KPIs of an enterprise, their significance and compliance with certain criteria should be taken into account (table 5)

Table 5

Analysis of compliance of working capital turnover with KPI definition criteria

\begin{tabular}{|l|c|l|}
\hline \multicolumn{1}{|c|}{ KPI characteristics } & $\begin{array}{c}\text { Analysis } \\
\text { of compliance }\end{array}$ & \multicolumn{1}{|c|}{ Justification } \\
\hline $\begin{array}{l}\text { 1. Understanding of the measure and } \\
\text { the corrective action required by all } \\
\text { staff }\end{array}$ & Yes & $\begin{array}{l}\text { Planning and economic department, accounting, sales } \\
\text { department and other departments are involved } \\
\text { in the work on the indicator control. }\end{array}$ \\
\hline 2. Nonfinancial measures & Yes & Measured as a percentage \\
\hline $\begin{array}{l}\text { 3. Measured frequently } \\
\text { 4. Acted on by the CEO and senior } \\
\text { management team }\end{array}$ & Yes & $\begin{array}{l}\text { Each of the components should be under operational } \\
\text { control (control over inventory levels, completeness } \\
\text { and timeliness of settlements with debtors and creditors, } \\
\text { etc.). }\end{array}$ \\
\hline $\begin{array}{l}\text { 5. Ties responsibility to the } \\
\text { individual or team }\end{array}$ & $\begin{array}{l}\text { Chief executive officer and member of the board have } \\
\text { to react promptly to changes in working capital turnover } \\
\text { by taking appropriate decisions }\end{array}$ \\
\hline $\begin{array}{l}\text { 6. Significant impact (affects most of } \\
\text { the core critical success factors) }\end{array}$ & $\begin{array}{l}\text { Controls over working capital turnover should } \\
\text { be the responsibility of the CFO or the employees } \\
\text { of the economic planning department }\end{array}$ \\
\hline $\begin{array}{l}\text { 7. Positive impact (affects all other } \\
\text { performance measures in a positive } \\
\text { way) }\end{array}$ & Yes & $\begin{array}{l}\text { The ability of the enterprise to fulfill its obligations } \\
\text { to consumers in a timely and high-quality manner } \\
\text { depends on the volume of working capital, which, } \\
\text { accordingly, is the key to the success of the enterprise }\end{array}$ \\
\hline
\end{tabular}

Resource: built by authors based on ${ }^{1}$

\footnotetext{
${ }^{1}$ Тарасенко, Л. О., Іонін, Є. Є. (2020) Достатність робочого капіталу як ключовий показник забезпечення ефективності діяльності операторів газорозподільних мереж. Theoretical foundations for the implementation and adaptation of scientific achievements in practic: the XXIIth International scientific and practical conference (Helsinki, 22-23 June, 2020), 275-279.

${ }^{2}$ Парментер, Д. (2008). Ключевые показатели эффективности. Разработка, внедрение и применение решающих показателей. Москва: Олимп-Бизнес.
} 
To achieve strategy goals, managerial staff should control working capital and working capital turnover. These indicators help achieve efficient activity.

Working capital turnover - relative indicator, which could be chosen as KPI for joint-stock companies - gas distribution enterprises - because it is an indicator of the generation of income, profit, cash flows that ensure the duration of business activities.

Conclusion. The dynamism and substantiality of the changes, typical for the modern stage of development of the natural gas market of Ukraine, cause the necessity to study the influence of changes on the activity of joint stock companies engaged in gas distribution.

Evaluation of the efficiency of the activity, control of its level and making of corresponding decisions is based on a certain amount of data on the work of the joint stock company. To this end, it is proposed to introduce a system of financial indicators that includes working capital and the ratios calculated on its basis.

The proposed indicators of working capital and turnover of working capital, profitability of working capital on accrual and cash base, security of income (sales) by working capital are guidelines for the development of management decisions and the achievement of efficiency. These indicators demonstrate a level of financial stability. In order to achieve efficiency and minimize risks, management staff should consider various options for managing working capital, and choose the strategy that best corresponds to the current state of the enterprise.

Since the system of indicators under consideration is crucial, it is proposed to consider working capital turnover as a key performance indicator (KPI). This indicator should be at the constant control of management personnel, requires a thorough in-depth analysis, as its changes have a direct impact on the financial stability, solvency of the enterprise, its functioning in accordance with the going-concern concept.

\section{References:}

1. Zakon pro rynok pryrodnoho hazu, 2015 (Verkhovna Rada Ukrajiny) [Law on the natural gas market (Verkhovna Rada of Ukraine)]. Oficijnyj visnik Ukrajiny [Official Bulletin of Ukraine], 37, 67. [in Ukrainian].

2. Proekt Zakonu Ukrainy pro vnesennia zmin do deiakykh zakonodavchykh aktiv Ukrainy shchodo zaprovadzhennia na rynku pryrodnoho hazu obliku ta rozrakhunkiv za obsiahom hazu v odynytsiakh enerhii 2020, 2019 (Verkhovna Rada Ukrajiny) [The Draft Law on amendments to some legislative acts of Ukraine regarding the introduction of metering and settlements of gas volume in units of energy on the natural gas market (Verkhovna Rada of Ukraine)] Ofitsiinyi sait Verkhovnoi Rady Ukrainy [The official website of the Verkhovna Rada of Ukraine] <http://w1.c1.rada.gov.ua/pls/zweb2/webproc4_1?pf3511=67572> (2020, September, 15).

3. Ionin, Ye.Ye. (2019). Diahnostyka vidpovidnosti platospromozhnosti bazovym kontseptsiiam bukhhalterskoho obliku [Diagnostic of compliance with payability to basic concepts of accounting]. Finansy, oblik, banky [Finance, accounting, banks], 1 (24), 129-137. [in Ukrainian].

4. Kvasnytska, R. S., Morozovskyi, Ya. E. (2019). Analiz pidkhodiv (stratehii) finansuvannia aktyviv pidpryiemstva [Analysis of approaches (strategies) of financing of assets of the enterprise]. Skhidna Yevropa: ekonomika, biznes ta upravlinnia [Eastern Europe: economy, business and management], 1 (18), 241-249. [in Ukrainian]

5. Tarasenko, L.O., Ionin, Ye.Ye. (2020). Dostatnist robochoho kapitalu yak kliuchovyi pokaznyk zabezpechennia efektyvnosti diialnosti operatoriv hazorozpodilnykh merezh [Working capital adequacy as a key indicator of ensuring the efficiency of gas distribution network operators]. Teoretychni osnovy vprovadzhennia ta adaptatsii naukovykh dosiahnen na praktytsi: materialy XXII Mizhnarodnoi naukovo-praktychnoi konferentsii (m. Helsinki, 22-23 chervnia $2020 \mathrm{r}$.). [Theoretical foundations for the implementation and adaptation of scientific achievements in practice: materials of the 22nd International scientific and practical conference (Helsinki, 22-23 June, 2020)], 275-279. [in Ukrainian].

6. Parmenter, D. (2008). Kliuchevye pokazateli effektivnosti. Razrabotka, vnedrenie i primenenie reshaiushchikh pokazatelei [Key Performance Indicators: Developing, Implementing, and Using Winning KPIs]. Moscow: Olimp-Biznes. [in Russian] 